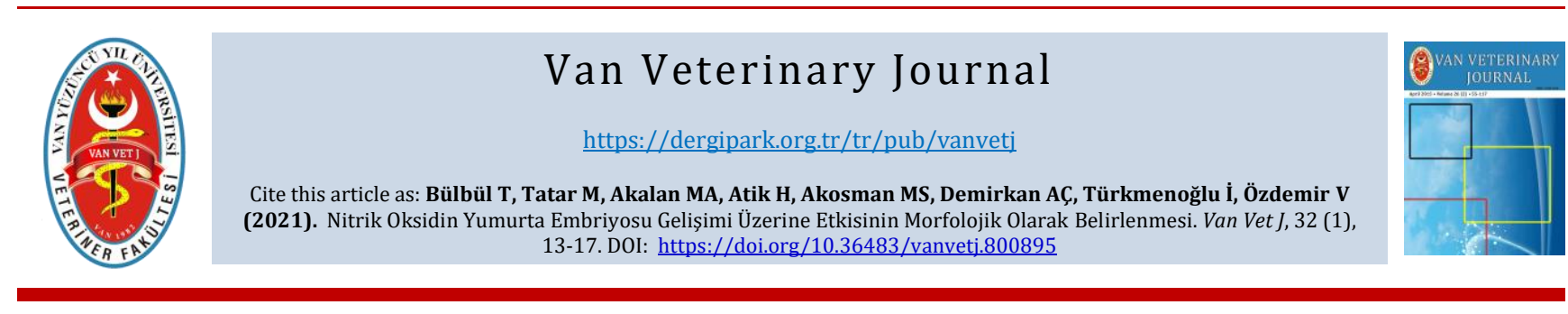

\title{
Morphological Determination of the Effect of Nitric Oxide on Egg Embryo Development
}

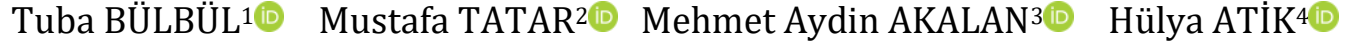

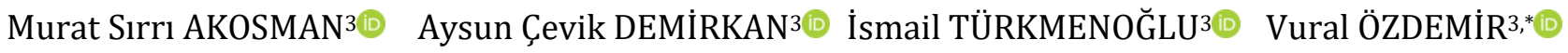 \\ ${ }^{1}$ Department of Animal Nutrition and Nutritional Diseases, Faculty of Milas Veterinary Medicine, Muğla Sıtkı Koçman University, Muğla, Turkey \\ ${ }^{2}$ Afyonkarahisar Directorate of Provincial Agriculture and Forestry \\ ${ }^{3}$ Department of Anatomi, Faculty of Veterinary Medicine, Afyon Kocatepe University, Afyonkarahisar, Turkey \\ ${ }^{4}$ Department of Physiology, Faculty of Veterinary Medicine, Afyon Kocatepe University, Afyonkarahisar, Turkey
}

Received: 28.09.2020

Accepted: 16.12 .2020

ABSTRACT This study was carried out to determine the effect of sodium nitroprusside (SNP), a nitric oxide (NO) exogenous donor, and NG-nitro-L-arginine methyl ester (L-NAME), a NO inhibitor, on the development of chicken embryos by injected into the egg. A total of 210 hatching fertilized chicken eggs used into control, Sham control (SC), serum physiological (SP) and treatment groups containing 30 eggs. The air space of the remaining eggs was pierced at the beginning of the incubation, whereas the eggs in the control group were not subjected to any application (negative control). The SC group of the drilled eggs was immediately closed with paraffin. After the SP group was called a positive control, 50 and $200 \mathrm{mg} / \mathrm{kg} \mathrm{SNP}$ respectively and L-NAME solutions at the same levels were injected into the hole opened to the air space into the experimental groups consisting of the remaining eggs. The eggs were opened on some days 7th and 14th of the embryonic period and the following parameters of each group were determined: Relative embryo weights, weights and lengths of the embryos (on days 7th and 14th), hatching weight, hatching length, hatching rate and embryonal deaths (on day 21st). The results showed that the relative embryo weight and embryo length on the days 7 th and 14th of the hatching and the hatching weight on the day 21st of the hatching were not affected by injection of SNP and L-NAME $(P>0.05)$. Hatching rate on the day $21^{\text {st }}$ was highest in the LNAME50 group, whereas this rate was lowest in the SNP200 group $(\mathrm{P}<0.05)$. Hatching length increased in the LNAME200 group $(\mathrm{P}<0.05)$. It was observed that $\mathrm{NO}$ was functional in embryonic development of poultry, and the increase in its metabolism decreased in the hatching rate increasing embryonal death.

Keywords: Chicken embryo, Embryotoxicity, L-NAME, SNP

\section{Nitrik Oksidin Yumurta Embriyosu Gelişimi Üzerine Etkisinin Morfolojik Olarak Belirlenmesi}

Bu araştırma, nitrik oksidin (NO’nun) ekzojen donörü sodyum nitroprussid (SNP) ve NO inhibitörü N-nitro-L-Arjinin metil esterin (L-NAME'in) yumurtaya enjeksiyon yapılarak kanatlı embriyonal gelișimi üzerinde oluşturduğu etkisini belirlemek amacıyla yapıldı. Araştırmada toplam 210 adet kuluçkalık döllü tavuk yumurtası her biri 30 yumurtadan oluşan kontrol, Sham kontrol (SK), serum fizyolojik (SF) ve deneme gruplarında kullanıldı. Kontrol grubundaki yumurtalara hiçbir uygulama yapılmazken (negatif kontrol), geri kalan yumurtaların kuluçka başlangıcında hava kamarası delindi. Delinen yumurtalardan SK grubu hemen parafinle kapatıldı. SF grubu pozitif kontrol olarak adlandırıldıktan sonra geriye kalan yumurtaların oluşturduğu deneme gruplarına sırasıyla 50 ve 200 $\mathrm{mg} / \mathrm{kg}$ SNP ve aynı düzeylerde L-NAME solüsyonları hava kamarasına açllan deliğe enjekte edildi. Embriyonik dönemin 7 ve 14. günlerinde yumurtalar açılarak gruplarda rölatif embriyo ağırlı̆̆ı ve embriyo uzunluğu (7. ve 14 . günlerde) ile çıkım ağırlı̆̆ı, çıkım uzunluğu, çıkım oranı ve embriyonal ölümler (21. günde) belirlendi. Kuluçkanın 7. ve 14. günlerindeki rölatif embriyo ağırlğ̆ı ve embriyo uzunluğu değerleri ile 21. güne ait çıkım ağırlı̆ıının SNP ve LNAME enjeksiyonundan etkilenmediği görüldü $(\mathrm{P}>0.05)$. Araștırmada 21. gününe ait çııım oranı L-NAME50 grubunda en yüksek iken, SNP200 grubunda en düşük olarak belirlendi $(\mathrm{P}<0.05)$. Çıkım uzunluğunun L-NAME200 grubunda arttığı tespit edildi $(\mathrm{P}<0.05)$. Sonuç olarak, NO'nun kanatlılarda embriyonal gelişimde fonksiyonel olmakla birlikte metabolizmasındaki artışın embriyonel ölümü artırarak kuluçka çıkım oranını azalttığı görüldü.

Anahtar Kelimeler: Embriyotoksisite, L-NAME, SNP, Tavuk embriyosu 


\section{GíRIŞ}

Nitrik oksit (NO), düşük molekül ağırlığına sahip, hidrofobik, gazsal yapılı ve hücre içi ile hücreler arası mesaj iletiminde rol oynayan serbest radikal bir moleküldür (Knowles ve Moncada 1994). Bu molekül memeli ve kanatlı hücresinde nitrik oksit sentaz (NOS) olarak bilinen enzim aracılığı ile L-arjinin aminoasidinden sentezlenmektedir (Knowles ve Moncada 1994, Choi ve ark. 1996). Nitrik oksitin gerek memelerde gerekse kanatlılarda tüm sistemler üzerine önemli fonksiyonları bulunmaktadır. Yapılan araştırmalarda NO donörleri (Sodyum Nitro Prussid, SNP; arjinin) ve inhibitörleri (Nnitro-L-arjinin metil ester, L-NAME; N-nitro-L-arjinin, LNNA, aminoguanidin, flunixin meglumin) kullanılarak NO'nun canlılar üzerine etkileri belirlenmeye çalıșılmıștır (Curran ve ark. 1990, Moncoda ve Higgs 1993, Bulbul ve ark. 2015a). Nitrik oksit, beyinde ve periferal sistemde folliküler gelişimin düzenlenmesi, ovulasyon mekanizması ve yumurta veriminde önemli rol oynayan maddelerden biridir (Manwar ve ark. 2006). Ovaryumda NOS enziminin varlığı kanatlılarda gösterilirken, lokal olarak ovaryumdan düșük düzeyde salınan NO'nun apoptozisi engelleyerek follüküler gelişimi uyardığı ifade edilmektedir (Kim ve ark. 2001). Nitrik oksitin primordial folliküllerden primer follikül, primerden ise sekonder folliküle geçişte görev aldığı belirtilmektedir (Bulbul ve ark. 2015b). Bununla birlikte aynı araștırmada SNP'nin $200 \mathrm{mg} / \mathrm{kg}$ düzeyinin ovaryumdaki primer ve premordiyal folliküllerin sayısını yükselttiği, dolayısıyla primer ve premordiyal folliküllerde dejenerasyonu engellediği gösterilmiștir.

Kanatlı embriyoları, özellikle tavuk embriyosu embriyonal çalışmalarda kullanılan bazı ilaçlar, gıda katkı maddeleri, endüstriyel bileşikler, pestisitler, ağır metaller, mikotoksinler ve diğer kimyasal maddelerin embriyotoksik, mutajenik, teratojenik ve genotoksik etkilerinin belirlenmesinde yapılan deneysel testlerde kullanımı en çok tercih edilen materyallerdendir (Heinrich-Hirsch ve Neuberti 1991). NO'nun memelilerde embriyo tarafindan da üretildiği ve bu şekilde oluşan NO'nun endometriyumda lokal damar genişlemesi ile hormonlar veya sitokinlerin düzenlenmesinde görev aldığ belirtilmektedir. Bununla birlikte NO'nun kullanım düzeyine bağlı olarak embriyonik kayıplara neden olabileceği ifade edilmektedir (Blashkiv ve ark. 2001, Chen ve ark. 2001, Lepiller ve ark. 2007). Buna karşın iNOS inhbitörü olan fluniksin megluminin (Öznurlu ve Öznurlu 2016) civciv embriyosu üzerine etkisini bildiren araştırma dışında NO'nun ekzojen donörü olan SNP ve inhibitörü olan L-NAME'in kanatlı embriyosu üzerine etkisi değerlendirilmemiştir. Nitrik oksit stimülasyonu ya da inhibisyonunun tavuk embriyosu üzerine etkilerinin araştırıldığı çalışmalar sınırlıdır. Yapılan bu araştırmada SNP ve L-NAME'in kanatlı embriyonal gelişimi üzerine olası etkisinin belirlenmesi amaçlandı.

\section{MATERYAL ve METOT}

Yumurtalar, Araştırma Grupları ve Enjeksiyonlar ile Kuluçka İşlemleri

Araştırma, Afyon Kocatepe Üniversitesi Hayvan Deneyleri Etik Kurulu'nun (AKÜHADYEK-103-18) onayını takiben, Afyon Kocatepe Üniversitesi Veteriner Fakültesi Anatomi Anabilim Dalı Laboratuvarı'nda bulunan kuluçka makinasında (Cimuka CT120SH, Türkiye) yürütüldü.

Araștırmada kanatlı anaçlardan elde edilen beyaz yumurtacı ırkı damızlıklara ait toplam 210 adet kuluçkalık döllü tavuk yumurtası kullanıldı. Işıklı kutuda muayene edilip normal poroziteye sahip olanlar araștırmaya dahil edildi. Yumurtalar birer birer tartılarak kuluçka başlangıç ağırlıkları belirlendi. Daha sonra her bir yumurta kapalı kabinde dezenfeksiyon amaciyla $21 \mathrm{~g}$ potasyum permanganat $42 \mathrm{~mL}$ formaldehit/ $\mathrm{m}^{3}$ karışımıyla elde edilen buhara maruz birakıldı.

Araştırmada 30 yumurta hiçbir uygulamanın yapılmadığı negatif kontrol grubu olarak ayrılırken, geri kalan 180 yumurta kuluçka başlangıcında hava kamarası özel yumurta delicisi ile delindi. Delinen yumurtalardan 30'u Sham Kontrol grubu (SK, delindikten sonra hemen parafinle kapatılacak olan grup), diğer 30'u serum fizyolojik grubu (SF, pozitif kontrol) olarak adlandırıldıktan sonra geriye kalan yumurtaların oluşturduğu deney gruplarına iki farklı dozda SNP (Sigma 71778) ve L-NAME (Sigma N5751) solüsyonları hava kamarasına açllan deliğe enjekte edildi (Prelusky ve ark. 1987, Celik ve ark. 2000). Bu işlem için yumurtanın küt ucunun dezenfeksiyonunu sonrası steril uçlu özel mikropipet (Sealpette, Jencons) kullanıldı. SNP ve L-NAME daha önce hayvanlarda (at, sığır, köpek, kedi, tavşan, hamster, kobay, gerbil, şinşilla, rat) sırasıyla 50-200 ve 50$200 \mathrm{mg} / \mathrm{kg}$ dozunda uygulandı (Bülbül ve ark. 2015a, b). Araștırmada ise SNP ve L-NAME gruplarında uygulama hacmi Serum Fizyolojik (SF) kullanılarak 0.025 ml şeklinde ayarlanarak yapıldı. Enjeksiyonların yapılmak üzere delindiği tüm hava kamaraları, sıvı parafinle kapatıldı. Daha sonra yumurtalar, önceden dezenfekte edilen dezenfeksiyonu yapılan $37.5^{\circ} \mathrm{C}$ sıcaklık, \% 65 nispi nem ve düzenli havalandırma koşullarının oluşturulduğu kuluçka makinasına uygun șekilde yerleștirildi. Burada her bir gruba ait yumurtaların her bir katta eşit sayıda olacak şekilde homojen yerleştirilmesine dikkat edildi. Ayrıca günde $12 \mathrm{kez}$ (her iki saatte bir) yumurtalar burada otomatik olarak $180^{\circ}$ lik $/ 45^{\circ}$ lik açıyla öne ve arkaya doğru döndürüldü. Böylece araştırmadaki tüm yumurtaların standart koşullar altında inkube edilmesi sağlandı.

\section{Embriyo Ağırlıkları ve Uzunluklarının Belirlenmesi}

Kuluçkanın 7. ve 14. günlerinde gruplardan rastgele alınan 10 yumurta birer birer hassas teraziyle tartılıp ağırlıkları belirlendi. Daha sonra bu yumurtalar yine aynı günlerde açlıp elde edilen embriyolar da aynı șekilde tartılarak embriyo ağırlıkları saptandı. Embriyo tepe-kıç uzunluğu (EU) dijital bir kumpasla (Mitutoyo Digimatic Caliper, CDN- P20PMX, Japan) ölçüldü (Şekil 1). Bu değerlerden yararlanılarak rölatif embriyo ağırlıkları (REA) aşağıdaki formüle göre bulundu:

Rölatif embriyo ağırlığı (\%)= (Embriyo ağırlığı / Yumurtanın son ağırlı̆̆ı) x 100

\section{Çıkım Oranı, Ağırlıkları ve Uzunluklarının Belirlenmesi}

Kuluçkanın 21. gününde gruplardan rastgele alınan 10 yumurta birer birer hassas teraziyle tartılıp ağırlıkları belirlendi. Daha sonra açılan bu yumurtaların embriyoları tartılarak çıkım ağırlıkları (ÇA) bulundu. Çıkım uzunluğu (ÇU) için embriyoların tepe ile kıç arasındaki uzunluk/ gaga ile orta tırnak arasındaki mesafe dijital bir kumpasla (Mitutoyo Digimatic Caliper, CDN- P20PMX, Japan) ölçüldü (Şekil 1). Kuluçkanın son gününde gruplarda çııım oranının (ÇO) belirlenmesinde aşağıdaki formül kullanıldı (Aksoy 1994). Çıkım Oranı (\%) = (Çıkan civciv sayısı $/$ Makineye konulan döllü yumurta sayısı) x 100 


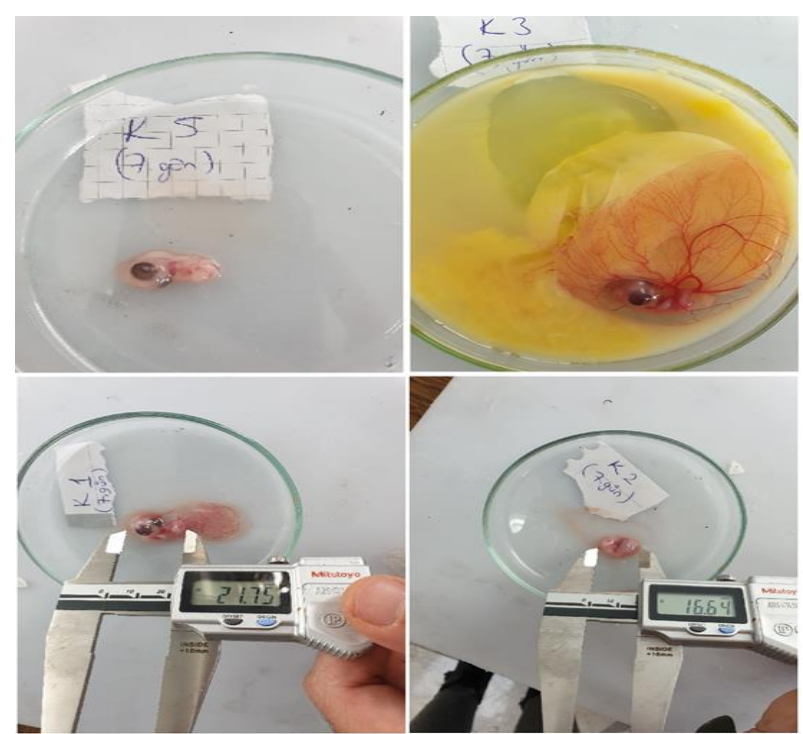

Şekil 1. Kontrol grubunda 7. güne ait görüntüler.

Figure 1. Images of the 7th day in the control group.

\section{Malformasyonlar ve Gelişme Geriliklerinin Belirlenmesi}

Kuluçkanın 21. gününe ait embriyoların gelişim dönemi yumurtalar tek tek kırlarak Hamburger ve Hamilton (1951) Skalasına göre değerlendirildi. Buna göre embriyolarda oluşan makroskobik anomaliler, gelişme geriliği, ölüm oranları değerlendirildi.

\section{İstatistiksel Analizler}

Embriyonik mortaliteler gruplardan elde edilen fertil yumurta sayılarına göre hesaplandı. Embriyonik mortalite verileri ki-kare testiyle değerlendirilirken, rölatif embriyo ve civciv ağırlı̆̆ ile tepe-kıç uzunluklarının değerlendirilmesinde One-Way Anova ve Tukey testi kullanıldı. İstatistiksel testler, SPSS (9.0.0 versiyonu) paket programı göre yapıldı. $\mathrm{P}<0.05$ değeri istatistiki açıdan önem sınırı kabul edildi.

\section{BULGULAR}

Araştırmada başlangıç (0 gün), 7., 14. ve 21. güne (yumurtadan çıııma) ait ölçümler sırasıyla Tablo 1 ve 2'de gösterilmektedir. Araștırmada gruplarda yumurta başlangıç ağırlıkları ile birlikte 7. ve 14. günlerdeki rölatif embriyo ağırlığı ve embriyo uzunluğu değerleri açısından herhangi bir fark saptanmadı ( $>>0.05$; Tablo 1, Şekil 1). Araştırmanın 21.gününe ait çlkım parametreleri incelendiğinde çıkım ağırlı̆̆ı bakımından kontrol ve deneme grupları arasında farklılık görülmemesine $(P>0.05)$ rağmen, çlkım oranı ve çıkım uzunluğunun deneme grupları arasında değiștiği tespit edildi $(\mathrm{P}<0.05$; Tablo 2). En yüksek çıkım oranı $\% 90$ ile kontrol grubunda gözlenirken; bunu sirasıyla SK (\% 83.3), SF (\% 76.7) ve deneme grupları izledi. Çıkım oranı deneme gruplarından L-NAME50 grubunda en yüksek (\% 70) iken, SNP200 grubunda en düşük ( $\% 40)$ olarak belirlendi. Çıkım uzunlukları incelendiğinde ise en farklı ve en yüksek değer L-NAME200 grubunda (91.66 mm) görülürken; kontrol (83.84 mm), SK (82,73 mm), SF (84.33 mm) grupları ile deneme gruplarının çıkım uzunlukları değerlerinin birbirine benzer olduğu tespit edildi. Araştırmanın 21.günündeki embriyolojik gelişim incelendiğinde kontrol grubundaki gelişimin Hamburger-Hamilton (1951) skalasına uygun olduğu gözlendi. Deneme gruplarında ise bu skalaya göre embriyolarda gelişim geriliği saptanırken; en fazla gelişim geriliği ve ölüm oranı SNP200 grubunda tespit edildi.

Tablo 1. Gruplara ait yumurta başlangıç ağırlığı (YBA) ile 7. ve 14. günlerdeki rölatif embriyo ağırlığı (REA) ve embriyo uzunluğu (EU) ortalamaları.

Table 1. The initial weight of the egg groups with mean relative embryo weight (REA) and embryo length (EU) on days 7 and 14 .

\begin{tabular}{lccccc}
\hline & YBA, g & $\begin{array}{l}\text { REA (7. } \\
\text { gün), \% }\end{array}$ & $\begin{array}{l}\text { EU (7.gün), } \\
\text { cm }\end{array}$ & $\begin{array}{l}\text { REA (14. } \\
\text { gün), \% }\end{array}$ & $\begin{array}{l}\text { EU } \\
\text { (14.gün), } \\
\mathbf{c m}\end{array}$ \\
\hline Kontrol & $51.63 \pm 0.81$ & $0.76 \pm 0.07$ & $24.11 \pm 0.99$ & $10.34 \pm 0.77$ & $48.90 \pm 2.75$ \\
SK & $50.46 \pm 0.60$ & $0.90 \pm 0.04$ & $25.67 \pm 0.29$ & $11.55 \pm 0.54$ & $49.06 \pm 2.44$ \\
SF & $51.13 \pm 0.59$ & $0.87 \pm 0.03$ & $25.42 \pm 0.19$ & $11.94 \pm 0.49$ & $52.51 \pm 3.68$ \\
SNP50 & $50.93 \pm 0.63$ & $0.81 \pm 0.05$ & $25.38 \pm 0.70$ & $11.41 \pm 0.44$ & $50.87 \pm 1.51$ \\
SNP200 & $51.73 \pm 0.63$ & $0.78 \pm 0.04$ & $25.02 \pm 0.74$ & $11.63 \pm 0.41$ & $53.04 \pm 4.06$ \\
L-NAME50 & $52.23 \pm 0.72$ & $0.83 \pm 0.10$ & $23.61 \pm 0.44$ & $10.74 \pm 0.49$ & $51.72 \pm 3.45$ \\
L-NAME200 & $51.63 \pm 0.59$ & $0.83 \pm 0.03$ & $24.33 \pm 0.55$ & $10.35 \pm 0.32$ & $53.10 \pm 2.50$ \\
\hline P & 0.580 & 0.660 & 0.324 & 0.216 & 0.888 \\
\hline
\end{tabular}

SK: Sham Kontrol, SF: Serum Fizyolojik, SNP: Sodyum Nitro Prussid, L-NAME: N-nitro-L-arjinin metil ester. Gruplar arasındaki fark istatistiksel açıdan önemsizdir $(\mathrm{P}>0.05)$.

Tablo 2. Gruplara ait çıkım oranı (ÇO), çıkım ağırlı̆̆ı (ÇA) ve çıkım uzunluğu (ÇU) ortalamaları.

Table 2. Hatching rate (HR), hatching weight (HW) and hatching length (HL) average in the groups.

\begin{tabular}{lccc}
\hline & Ç0, $\%$ & ÇA, $\mathbf{g}$ & ÇU, mm \\
\hline Kontrol & 90 & $34.31 \pm 1.30$ & $83.84 \pm 0.30^{\mathrm{a}}$ \\
SK & 83.3 & $34.19 \pm 1.15$ & $82.73 \pm 0.52^{\mathrm{a}}$ \\
SF & 76.7 & $34.27 \pm 0.65$ & $84.33 \pm 0.93^{\mathrm{a}}$ \\
SNP50 & 53.3 & $35.24 \pm 0.93$ & $84.45 \pm 0.96^{\mathrm{a}}$ \\
SNP200 & 40 & $37.14 \pm 0.98$ & $84.40 \pm 0.88^{\mathrm{a}}$ \\
L-NAME50 & 70 & $34.44 \pm 0.95$ & $84.95 \pm 1.39^{\mathrm{a}}$ \\
L-NAME200 & 60 & $38.43 \pm 0.90$ & $91.66 \pm 0.82^{\mathrm{b}}$ \\
\hline P & 0.000 & 0.053 & 0.000 \\
\hline
\end{tabular}

SK: Sham Kontrol, SF: Serum Fizyolojik, SNP: Sodyum Nitro Prussid, L-NAME: N-nitro-L-arjinin metil ester. a,b: Aynı satırda farklı harfleri taşıyan ortalamalar arası fark önemlidir $(\mathrm{P}<0.001)$

\section{TARTIŞMA ve SONUÇ}

Kanatlı embriyoları özellikle tavuk embriyosu, kimyasal maddelerin embriyotoksik etkilerinin de belirlenmesinde yapılan testlerde tercih edilen materyallerdendir (Ubeda ve ark. 1994). Bu amaçla geliștirilen testlerden biri Tavuk Embriyotoksisite Belirleme Testi'dir (Chicken Embryotoxicity Screening Test, CHEST'dir). Bu testin birinci așamasından elde edilen sonuçların morfogenetik durumlar yönünden memelilerle uyumlu özelliklere sahip olduğu tespit edilmiştir (Jelinek ve ark. 1985, Jelinek ve Marhan 1994). Özellikle erken dönem civciv embriyo modelinin, memelilerdeki embriyonik gelişimin ilk ayına benzer olduğu belirtilmektedir (Unlu 2002). Bununla birlikte prenatal etkinin değerlendirilmesi açısından kullanılan CHEST; embriyosunun gelişim dönemlerinin çok iyi belirlenebilmesi, çok sayıda embriyonun kullanılabilmesi, canlı bir organizmaya verilebilecek verebileceği ağrı ve acıyı en aza indirgemesi gibi avantajlara sahiptir (Jelinek ve ark. 1985). Bu bağlamda mevcut çalışmada NO'nun embriyotoksik etkilerinin belirlenebilmesi için döllü tavuk yumurtalarına enjeksiyonlar gerçekleştirildi. 
Embriyotoksisite çalıșmalarında kullanılan maddenin uygulama yeri, zamanı, dozu ve özellikleri (doğal, yapay formu), kullanılan çözücünün özellikleri (hacmi ve pH'sı) oldukça önem taşımaktadır (Jelinek ve Marhan 1994). Bu çalışmalarda uygulanacak kimyasalın hava kamarası, albümin ve yumurta sarısına enjeksiyonları denenmiş; uygulama ve sterilizasyon işlemlerinin kolaylığı, verilen solüsyonun hızlı ve homojen yayılması, yumurta içi basıncı artırarak embriyoda mekanik hasara yol açmaması gibi avantajları nedeniyle mevcut çalıșmada kimyasalların hava kamarasına uygulanması tercih edilmiştir. Yumurtaya enjekte edilecek maddenin farklı dozlarda uygulanması, sonuçların güvenilirliği açısından oldukça önemlidir (Celik ve ark. 2000, Cetinkal ve ark. 2010, Oznurlu ve Oznurlu 2016). Daha önce yapılan çalışmalarda (Bülbül ve ark. 2015a, b) kanatlılarda 50 ve 200 mg/kg SNP ve L-NAME'in nitrik oksit metabolizması üzerinde etkili olduğu ifade edilmesinden dolayı bu çalışmada da benzer dozlar uygulanmıștır. Uygulama hacmi olarak da $0.025 \mathrm{ml}$ (Celik ve ark. 2000) kullanılmıştır.

Kanatlılarda yumurta ağırlığı ve civciv çıkım ağırlığı arasında pozitif bir ilişki bulunmaktadır (Tona ve ark. 2004). Çıkan civcivlerin büyüklüğü, doğrudan doğruya yumurta büyüklügüne bağlıdır. Bu araştırmada çalışma öncesi gruplardaki yumurtaların ağırlıkları benzer olup 7 ., 14. günlerde embriyo ile çıkım günü ağırlıkları bakımından gruplar arasında fark görülmemiştir. Nitrik oksit dönürü SNP'nin yumurtaya enjeksiyon yapılarak kullanımına ilişkin daha önce yapılmış bir çalışma bulunmamasına karșın, (Lepiller ve ark. 2007) zebra balığının embriyonal gelişim boyunca fizyolojik ve stres koșullarında sürekli bir NO üretimi olduğunu ifade etmektedirler. Buna karşın bu çalışmadan farklı olarak (Oznurlu ve Oznurlu 2016) yaptıkları araştırmada iNOS inhibitörü olan aynı zamanda nonsteroid antiinflamutuar olan fluniksin megluminin dozuna bağlı olarak özellikle embriyonik dönemin 7., 11. 15. ve 18. günlerinde rölatif embriyo ağırlıkları ve embriyo uzunlukları ile kuluçkadan çıkış günü civciv ağırlıkları üzerinde azalmaya neden olduğunu bildirilmişlerdir. Bu çalışmada kullanılan L-NAME ise selektif bir NOS inhibitörü olup spesifik üç NOS enzimini (eNOS, iNOS, cNOS) de engellemektedir. Fluniksin megluminin ise NOS'tan bağımsız olarak damar genișletici bir madde olan prostaglandin sentezini engelleyerek embriyonal gelişim üzerinde olumsuz etki oluşturduğu düşünülebilir (Reppert ve ark. 2019).

Kanatlılarda döllü yumurtalardan çıkan civcivlerin yüzdesi olarak ifade edilen çıkım oranı, kuluçka sonuçlarının değerlendirilmesi açısından oldukça önemlidir. Çıkım oranının belirlenmesinde özellikle yumurtaların bulunduğu kuluçka makinesi koşullarının uygunluğu, kuluçkalık yumurtaların seçimi ve kalite özellikleri (yumurta ağırlığı gibi), döllülük gibi faktörler etkili olmakla birlikte (Ensminger 1992) kuluçkadaki yumurtalardaki embriyo gelişim dönemleri ile yumurtalara uygulanan maddeler çıkım oranını değiștirmektedir. Embriyotoksisite çalıșmalarında gözlemlenen embriyonik ölümlerin, embriyolarda önemli yapısal ve fonksiyonel bozuklukların çoğunlukla mitoz bölünme ve hücre farklılaşmasının hızlı gerçekleștiği erken gelişme dönemlerinde yoğunlaştığı görülmüştür (Kucera ve Burnand 1987). Bu nedenle mevcut araştırmada embriyonal gelişimin 21. gününe ait mortalite ve gelişim geriliklerine göre gruplarda çıkım oranları belirlendi. Buna göre embriyonal gelișimin 21. gününe ait çıkım oranı deneme gruplarından L-NAME50 grubunda en yüksek (\% 70) iken, SNP200 grubunda en düșük (\% 40) olarak tespit edildi $(\mathrm{P}<0.05$; Tablo 2).
Yapılan çalıșmalarda NO'nun metabolizma artıșı ve azalışının embriyonal gelişimi etkiledi farklı araştırmalarda saptanmıștır. Fare embriyoları üzerine yapılan çalışmada NO'nun normal embriyo gelişimi için gerekli olduğu, bir NOS inhibitörü olan NG-nitro-L-arginine maruz bırakılan embriyolarda normal gelişimin inhibe edildiği gösterilmiştir (Gouge ve ark. 1998). Fare embriyolarında $0.1-1 \mu \mathrm{M}$ dozundaki L-NAME'in blastosit gelişimini inhibe ettiğini, ancak $0.1 \mu \mathrm{M}$ SNP'nin bu etkileri tersine çevirdiğini, aşırı NO'nun $(\geq 10 \mu \mathrm{M})$ fare embriyolarında apoptoza neden olabileceğini bildirmişlerdir (Chen ve ark. 2001). Farelerde erken embriyonik ölümlerin nedenlerinin araștırıldığı bir çalıșmada (Haddad ve ark. 1995) gebe farelere gebeliğin 6 . gününden itibaren oral veya parenteral olarak verilen aminoguanid'in NOS inhibisyonuna neden olduğu ve erken embriyo ölümlerini azalttığı saptanmıștır. Mevcut araştırmada bu çalışmadaki verilere uyumlu olarak SNP verilen iki grupta da çıkımdaki ölüm oranı (SNP50: \% 46.7; SNP200: \% 60), L-NAME verilen iki gruptaki ölüm oranına (L-NAME50: \% 30; L-NAME200: \% 40) göre daha yüksek olarak saptand.

Bu araștırmada SNP'nin yüksek dozda uygulandığı grupta 21. günde embriyolarda gelişme geriliğinin arttığı tespit edildi. Embriyo tarafından da üretilmekte olan NO, endometriyumda lokal damar genişlemesi ile hormonlar veya sitokinlerin düzenlenmesinde önemli rol oynamaktadır. Bunun yanında NO, embriyoda damarlaşmayı artırmaktadır. Ancak oluşan NO'nun fizyolojik sınırlarda kalmasının önemli olduğu, yüksek düzeylerdeki NO'nun, embriyodaki apoptozisi uyararak embriyo kaybına neden olabildiği bildirilmektedir. Nitrik oksit eksikliğinde de süperoksit radikali yeterince uzaklaştırılamadığı için embriyonik hücrelerde hasar meydana geldiği ve embriyonik kayıp oluştuğu belirtilmektedir (Blashkiv ve ark. 2001, Chen ve ark. 2001). Bu araştırmada da NO donörü olan SNP200 grubunda görülen çıkım oranındaki azalma her embriyonun kendi gelişim sürecine bağlı olabileceği gibi, SNP'nin yüksek dozunun etkisiyle (SNP'nin yüksek dozuna embriyonun duyarlı olduğu) vitellin damarların yapısındaki bozulmaya bağlı olarak embriyoların yeterli beslenememesinden kaynaklanan gelişme bozuklukları ve ölüm oranı artışlarının (son dönem embriyo ölümlerinin) bu dönemde görülmesinden kaynaklanabilir.

Sonuç olarak bu çalışmada embriyonik gelişim döneminde NO metabolizmasında değișikliklerin embriyonal gelișimi bozduğu; özellikle NO donörü SNP'nin daha belirgin embriyotoksik etki gösterdiği görüldü. Ayrıca ileride yapılacak çalışmalarda doz ve grup sayılarının artırılması, embriyolarda organların histolojik yapılarının incelenmesi, stereolojik olarak hücre sayımı ve hacim hesaplamalarının yapılmasının NO'nun embriyo üzerine etkilerinin daha detaylı olarak anlaşılmasına katkı sağlayacağı düşünülmektedir.

\section{ÇIKAR ÇATIŞMASI}

Yazarlar, çıkar çatışması olmadığını beyan eder.

\section{TEŞEKKÜR}

Bu çalışma Afyon Kocatepe Üniversitesi Bilimsel Araştırma Projeleri Birimi tarafından 18.KARIYER. 253 No'lu proje numarası ile desteklenmiştir. 


\section{YAZAR KATKILARI}

Fikir/Kavram: TB, VÖ

Tasarım: TB, VÖ, MAA, MT

Denetleme/Danıșmanlık: MAA, HA, MSA, AÇD, İT

Veri Toplama ve/veya İşleme: TB, VÖ

Analiz ve/veya Yorum: TB, VÖ, MAA, MT

Kaynak Taraması: TB, VÖ

Makalenin Yazımı: Makalenin Yazımı: TB, VÖ

Eleştirel İnceleme: TB, VÖ, MAA, MT

\section{KAYNAKLAR}

Blashkiv TV, Korniichuk AN, Voznesenskaya TY, Pornichenko AG (2001). Role of nitric oxide in ovulation, meiotic maturation of oocytes, and implantation in mice. B Exp Biol Med, 132(5), 1034-1036.

Bulbul T, Akosman MS, Yllmaz O, Ulutas E, Bulbul A (2015a). Supplementary dietary nitric oxide donor (sodium nitroprusside) or inhibitor (NG-nitro-l-arginine methyl ester) depressed growth performance and ovarian primordial and primary follicles in Japanese quail (Coturnix coturnix japonica) in a dose-dependent manner. $\mathrm{Br}$ Poult Sci, 56(1), 113-120.

Bulbul A, Bulbul T, Ozdemir V, Akosman MS, Ulutas E, Yilmaz o. (2015b).Biphasic effect of nitric oxide on development of ovarian primordial and primary follicles in laying quail. Eur Poultry Sci, 79-90.

Chen HW, Jiang WS, Tzeng CR. (2001). Nitric oxide as a regulator in preimplantation embryo development and apoptosis. Fertil Steril, 75, 1163-1171.

Choi YH, Ohno N, Okumura J, Furuse M. (1996). Effects of pheripheral nitric oxide on food intake in the chick. J Poult Sci, 33(5), 286-291.

Curran RD, Billiar TR, Stuehr DJ, Ochoa JB, Harbrecht BG, Flint SG, Simmons RL. (1990) Multiple cytokines are required to induce hepatocyte nitric oxide production and inhibit total protein synthesis. Ann Surg, 212, 462-71.

Celik I, Oguz H, Demet O, Boydak M, Donmez HH, Sur E, Nizamlıglu F. (2000). Emryotoxicity assay of aflatoxin produced by Aspergillus parasiticus Nrrl 2999. Br Poult Sci, 41, 401-409.

Cetinkal A, Colak A, Topuz K, Demircan MN, Simsek N, Berber U, Umur AS, Selcuk M, Vatansever HS (2010). The effects of meloxicam on neural tube development in the early stage of chick embryos. Turk Neurosurg, 20, 111-116.

Ensminger, ME. (1992). Poultry Science. Interstate Publishers, Inc. 510 North Vermilion Street. P.O. Box 50. Printed in USA, Chapter. 3, 43-63.

Gouge RC, Marshburn P, Gordon BE, Nunley W, Huet-Hudson YM (1998). Nitric oxide as a regulator of embryonic development. Biol Reprod, 58, 875-879.

Haddad EB, Liu SF, Salmon M, Robichaud A, Barnes PJ, Chung KF (1995). Expression of inducible nitric oxide synthase mRNA in Brown
Norway rats exposed to ozone: effect of dexamethasone. Eur $J$ Pharmacol, 293, 287-290.

Hamburger V, Hamilton HL (1951). A series of normal stages in the development of chick embryo. J Morphol, 88, 49-92.

Heinrich-Hirsch B, Neuberti D (1991). Effect of aciclovir on the development of the chick embryo in ovo. Arch Toxicol, 65, 402-408.

Jelinek R, Marhan 0 (1994). Validation of chick embryotoxicity screening test (CHEST). A comparative study. Funct Dev Morphol, 4, 317-323.

Jelinek R, Peterka M, Rychter Z (1985). Chick embryotoxicity screening test-130 substances tested. Indian Exp Biol, 23, 588-595.

Kim PK, Zamora R, Petrosko P, Billiar TR (2001). The regulatory role of nitric oxide in apoptosis. Int Immunopharmacol, 1, 1421-1441.

Knowles RG, Moncada, S (1994). Nitric oxide synthases in mammals. Biochem J, 298(2), 249-258.

Kucera P, Burnand MB (1987). Routine teratogenicity test that uses chick embryos in vitro. Teratog Carcinog Mutagen, 7, 427-447.

Lepiller S, Laurens V, Bouchot A, Herbomel P, Solary E, Chluba J (2007). Imaging of nitric oxide in a living vertebrate using a diaminofluorescein probe. Free Radic Biol Med, 43, 619-627.

Manwar SJ, Moudgal RP, Sastry KVH, Mohan J, Tyagi JBS, Raina R (2006). Role of nitric oxide in ovarian follicular development and egg production in Japanese quail (Coturnix coturnix japonica). Theriogenology, 65, 1392-1400.

Moncoda S, Higgs A (1993). The L-arjinine-nitric oxide pathway. $N$ Engl J Med, 329, 2002-2012.

Öznurlu M, Öznurlu Y (2016). Erken dönemde yumurtaya enjekte edilen fluniksin megluminin embriyotoksik ve teratojenik etkilerinin belirlenmesi. Eurasian Journal of Veterinary Sciences, 32, 260-267.

Prelusky DB, Hamilton RMG, Foster BC, Trenholm HL, Thompson BK (1987). Optimization of chick embryotoxicity bioassay for testing toxicity potential of fungal metabolites. J Assoc Off Anal Chem, 70, 10491055

Reppert EJ, Kleinhenz MD, Montgomery SR, Heiman J, Sura A, Bornheim HN, Magnin G, Sidhu PK, Zhang Y, Joo H, Coetzee JF, (2019). Pharmacokinetics and pharmacodynamics of intravenous and transdermal flunixin meglumine in alpacas. $J$ Vet Pharmacol Ther, 42(5), 572-579.

Tona K, Onagbesan 0, De Ketelaere B, Decuypere E, Bruggemen V. (2004). Effects of age of broiler breeders and egg storage on egg quality, hatchability, chick quality, chick weight and chick posthatch growth to forty-two days. J Appl Poultry Res, 13, 10-18.

Ubeda A, Trillo MA, Chacon I, Blanco MJ, Jocelyne I. (1994) Chick embryo development can be irreversibly altered by early exposure to weak extremely-low-frequency magentic fields. Bioelectromagnetics, 15, 385-398.

Unlu A. (2002). Methods of developmental research. Acta Neurochir (Wien), 83, 71-78. 